\title{
Model Bangkitan Perjalanan Penduduk Perumahan Pinggiran Kota (Studi Kasus Perumahan Bukit Bambe Driyorejo Gresik)
}

\author{
Model of Trip Generation by Population \\ Suburban Housing \\ (Case Study of Bukit Bambe Driyorejo Gresik Housing)
}

\author{
Anita Susanti ${ }^{1}$, R Endro Wibisono ${ }^{2}$, Emil Andrean Kusuma ${ }^{3}$ \\ ${ }^{1}$ Jurusan Teknik Sipil, Fakultas Teknik, Universitas Negeri Surabaya, Jln. Ketintang Surabaya. Email : \\ anitasusanti.pasmar@gmail.com \\ ${ }^{2}$ Jurusan Teknik Sipil, Fakultas Teknik, Universitas Negeri Surabaya, Jln. Ketintang Surabaya. Email : \\ endrowibisono@unesa.ac.id \\ ${ }^{3}$ Jurusan Teknik Sipil, Fakultas Teknik, Universitas Negeri Surabaya, Jln. Ketintang Surabaya. Email : \\ emil.andrean@gmail.com
}

\begin{abstract}
Abstrak
Perumahan Bukit Bambe terletak di desa Bambe, kecamatan Driyorejo kabupaten Gresik. Adanya perumahan Bukit Bambe Gresik akan menimbulkan bangkitan perjalanan yang akan membebani jalur-jalur tertentu terutama pada Jalan Raya Mastrip yang selama ini dikenal dengan jalan rawan kemacetan karena land use di ruas jalan Raya Mastrip merupakan daerah perindustrian dimana terdapat banyak pabrik di sekitarnya, sehingga perlu diketahui model bangkitan perjalanan dari perumahan Bukit Bambe. Pengumpulan data dilakukan dengan dua metode yaitu survei primer dan survei sekunder. Untuk menghasilkan model bangkitan perjalanan pada studi ini digunakan metode analisa regresi linier yang dibantu perangkat lunak komputer SPSS 17. Karakteristik pedududuk perumahan Bukit Bambe yaitu jumlah anggota keluarga $51 \%$ berjumlah 4 orang, jumlah pendapatan 39\% sebesar Rp. 6.000.000,00 - Rp. 8.000.000,00, jumlah pegawai, mahasiswa dan pelajar $39 \%$ berjumlah 3 orang, Jumlah kepemilikan sepeda motor $46 \%$ memiliki 2 unit, dan jumlah kepemilikan mobil 60\% tidak memiliki mobil. Sedangkan untuk karakteristik perjalanan penduduk perumahan Bukit Bambe yaitu jumlah biaya transportasi $47 \%$ sebesar Rp. 0. - Rp. 19.999,00, jumlah lama waktu perjalanan 41\% selama 31 60 menit, jumlah jarak perjalanan 38\% sebesar 16 - $30 \mathrm{~km}$, jumlah perjalanan $38 \%$ berjumlah 6 perjalanan, moda transportasi yang digunakan 74\% menggunakan sepeda motor dan tujuan perjalaan 41,8\% menuju ke zona Surabaya Selatan yaitu kecamatan Karang Pilang, Wiyung, Gayungan, Wonokromo, Dukuh Pakis, Jambangan, Wonocolo dan Sawahan. Model bangkitan perjalanan yang dihasilkan yaitu $Y=0,014+0,023 X 1$ $+3,313 \times 10-8$ X2 + 1,934 X3-0,137 X4-0,122 X5 - 1,291 x 10-6 X6 + 0,004 X7 + 0,001 X8. Berdasarkan model tesebut, jumlah bangkitan peenduduk perumahan Bukit Bambe untuk setiap KK sebesar 6 perjalanan perhari dan untuk total keseluruhan bangkitan penduduk perumahan Bukit Bambe sebesar 8072 perjalanan perhari.
\end{abstract}

Kata Kunci: Bangkitan perjalanan; analisis model; perumahan

\begin{abstract}
Bukit Bambe Housing is located in Bambe village, Driyorejo sub-district, Gresik district. The existence of Bukit Bambe Gresik housing will cause a trip generation that will overload certain routes, especially on Jalan Raya Mastrip which has been known as a road prone to congestion because land use on Jalan Raya Mastrip is an industrial area where there are many factories around it, so it is necessary to know trip generation model from the Bukit Bambe housing complex. Data collection was carried out by two methods, namely primary survey and secondary survey. To produce a trip generation model in this study, a linear regression analysis method was used that was assisted by SPSS 17 computer software. The characteristics of the residents of the Bukit Bambe housing complex are that the number of family members is 51\%, 4 people, the total income is $39 \%$ of Rp. 6,000,000.00 - Rp. 8,000,000.00, the number of employees, students and students is 39\%, 3 people, 46\% of motorbikes own 2 units, and 60\% of car owners do not own a car. As for the travel characteristics of the
\end{abstract}


residents of the Bukit Bambe housing complex, namely the total transportation cost of $47 \%$ of Rp. 0 . - Rp. 19,999.00, total travel time 41\% for 31 - 60 minutes, total travel distance of $38 \%$ of $16-30 \mathrm{~km}, 38 \%$ of trips amounted to 6 trips, 74\% of the modes of transportation used were motorbikes and travel destinations $41.8 \%$ heading to the South Surabaya zone, namely Karang Pilang, Wiyung, Gayungan, Wonokromo, Dukuh Pakis, Jambangan, Wonocolo and Sawahan districts. The resulting trip generation model is $Y=0.014+0.023 X 1+$ $3,313 \times 10-8 \times 2+1,934 X 3-0.137 X 4-0.122 \times 5-1.291 \times 10-6$ X6 + 0.004 X7 + 0.001 X8. Based on this model, the total population generation of Bukit Bambe housing for each family is 6 trips per day and for the total population generation of the Bukit Bambe housing population is 8072 trips per day.

Keywords: Trip generation; model analysis; housing

\section{PENDAHULUAN}

Perkembangan aktivitas kota mengakibatkan pertumbuhan penduduk yang semakin besar yang berdampak pada meningkatnya kebutuhan perumahan sebagai kebutuhan pokok manusia. Di daerah perkotaan masalah pemukiman memang sangat terasa dibandingkan dipedesaan. Hal tersebut dikarenakan luas wilayah perkotaan yang relatif tetap berbanding dengan jumlah penduduk yang terus bertambah yang tentu saja membutuhkan rumah untuk hunian.

Semakin bertambahnya kebutuhan manusia akan perumahan menimbulkan banyaknya pembangunan suatu komplek perumahan di pinggiran kota. Hal ini merupakan konsekuensi yang tidak dapat dihindari karena rumah merupakan kebutuhan pokok manusia yang harus terpenuhi. Pengembangan komplek perumahan apabila tidak di perhatikan penempatannya dalam tata ruang wilayah dapat menimbulkan bangkitan lalu lintas yang dapat mempengaruhi keseimbangan transportasi pada jaringan jalan di sekitarnya. Suatu lokasi perumahan dapat dikatakan baik apabila mempunyai aksesbilitas yang baik dan mudah serta aman untuk manusia beraktifitas (bekerja/bersekolah). Hal ini berarti sistem transportasi di kawasan perumahan tersebut harus di atur dengan baik.

Perkembangan serta pertumbuhan penduduk kota Surabaya yang pesat menyebabkan kebutuhan perumahan juga meningkat. Hal ini menjadi salah satu penyebab dibangunnya berbagai kawasan perumahan di Surabaya oleh para pihak pengembang perumahan. Tetapi untuk mendapatkan lahan yang luas di pusat kota tidaklah mudah, maka pembangunan perumahan bergeser dari pusat perkotaan ke daerah pinggiran kota bahkan sampai memasuki batas wilayah daerah lain, salah satumya adalah perumahan yang di bangun oleh PT. Bambe Surya Sinar Timur yaitu perumahan Bukit Bambe. Perumahan Bukit Bambe terletak di Desa Bambe, Kecamatan Driyorejo Kabupaten Gresik berjarak $1,8 \mathrm{~km}$ dari jalan raya Cangkir yang terhubung dengan jalan raya Mastrip yang berjarak 3,4 km dari jembatan Sepanjang. Perumahan Bukit Bambe akan terus berkembang. Saat ini sudah dibangun 1500 unit rumah yang terbagi atas 6 macam tipe rumah, yaitu tipe 21, 27, 29, 36, 45, dan 54. Sementara itu rumah yang sudah ditempati yaitu 1178 unit yang terdiridari $11 \mathrm{KK}$ menempati rumah tipe 21, 156 KK menempati rumahtipe $27,118 \mathrm{KK}$ menempati rumah tipe 29, $731 \mathrm{KK}$ menempati rumah tipe 36, $106 \mathrm{KK}$ menempati rumah tipe 45 , dan $56 \mathrm{KK}$ menempati rumah tipe 54. Menurut rencana pengembang jumlah unit rumah di perumahan tersebut masih terus akan bertambah hingga mencapai 2000 unit rumah. Dengan adanya perumahan Bukit Bambe Gresik pasti akan menimbulkan bangkitan perjalanan yang akan membebani jalur - jalur tertentu terutama pada Jalan Raya Mastrip. Dari hasil survey pendahuluan (survei LHR) pada jam puncak pagi yaitu jam 06.00 - 09.00 WIB didapat data sebagai berikut :

Tabel 1. Hasil Survei Lalu Lintas

\begin{tabular}{cccc}
\hline $\begin{array}{c}\text { Jenis } \\
\text { Kendaraan }\end{array}$ & $\begin{array}{c}\text { Jumlah } \\
\text { kendaran } \\
\text { dari arah } \\
\text { Driyorejo }\end{array}$ & $\begin{array}{c}\text { Jumlah } \\
\text { kendaraan } \\
\text { dari arah } \\
\text { Perumahan }\end{array}$ & $\begin{array}{c}\text { Persentase } \\
\text { kendaraan dari } \\
\text { perumahan }\end{array}$ \\
\hline Motor & 3047 & 946 & $31 \%$ \\
Mobil & 233 & 82 & $35 \%$ \\
\hline
\end{tabular}

Sumber : Survei Lapangan,

Dari hasil survey pendahuluan tersebut diketahui bahwa $31 \%$ pengguna sepeda motor di jalan Mastrip berasal dari perumahan Bukit Bambe dan $35 \%$ pengguna mobil pribadi di jalan Mastrip berasal dari perumahan Bukit Bambe. Dapat diartikan bahwa kontribusi kendaraan pribadi dari perumahan Bukit Bambe pada jalan raya Mastrip sangat besar.

Jalan Raya mastrip selama ini dikenal dengan jalan rawan kemacetan karena land use di ruas jalan Raya Mastrip merupakan daerah perindustrian dimana terdapat banyak pabrik di sekitarnya. Hal ini akan menyebabkan menurunnya kinerja jalan yang 
berakibat pada gangguan aktifitas dan pergerakan manusia dan barang dari dalam maupun luar kota. Gangguan pergerakan lalu lintas berupa kemacetan, kecelakaan, berkurangnya kecepatan yang tidak sesuai kecepatan rencana, pelanggaran lalu lintas dan lain sebagainya merupakan indikasi penurunan kinerja jalan (Tamin, 2000).

Di kecamatan Driyorejo selain perumahan Bukit Bambe terdapat beberapa perumahan lain, diantaranya perumahan "Kota Baru Driyorejo", "Griya Kencana", "Griya Sumput Asri", dan "Patria Permai". Perumahan Kota Baru Driyorejo, Griya Kencana dan Griya Sumput Asri untuk menuju kota Surabaya ada dua jalur alternatif terdekat yaitu melewati jalanraya Menganti dan jalan raya Mastrip. Sedangkan perumahan Bukit Bambe dan Patria Permai untuk menuju kota Surabaya hanya ada satu jalur alternatif terdekat yaitu melewati jalan raya Mastrip. Dari jumlah unit rumah yang terbangun antara perumahan Bukit Bambe dan Patria Permai, perumahan Bukit Bambe merupakan perumahan terbesar dengan 1500 unit rumah dan akan berkembang mencapai 2000 unit rumah. Sedangkan perumahan Patria hanya terdapat 100 unit rumah yang terbangun.

Oleh karena itu perlu dilakukan studi terhadap perumahan tersebut. Dalam studi ini akan diarahkan pada analisa karakteristik dan pola perjalanan dengan judul "Model Bangkitan Perjalanan Penduduk Perumahan Pinggiran Kota (Studi Kasus Perumahan Bukit Bambe Driyorejo Gresik)".

Dari latar belakang yang diuraikan sebelumnya, maka beberapa rumusan masalah yang didapat adalah bagaimana karakteristik perjalanan penduduk perumahan Bukit Bambe Gresik yang melewati jalan raya Mastrip?, bagaimana model bangkitan perjalanan di tinjau dari karakteristik rumah tangga penduduk perumahan Bukit Bambe Gresik yang melewati jalan raya Mastrip?, bagaimana penerapan dari model bangkitan perjalanan yang dihasilkan?

Agar pembahasan yang dibahas dalam penulisan karya ilmiah ini tidak melebihi di luar pembahasan, maka pembahasan perlu dibatasi. Batasan - batasan tersebut yaitu : Studi hanya di lakukan di perumahan Bukit Bambe Driyorejo Gresik.

Pengumpulan data diperoleh menggunakan metode pengumpulan sampel dengan penyebaran kuisioner kepada masing - masing rumah (Home Interview Survey).Karakteristik bangkitan perjalanan yang ditinjau adalah karakteristik rumahtangga dan karakteristik perjalanan penduduk perumahan Bukit Bambe Driyorejo Gresik. Variabel karakteristik rumah tangga dan karakteristik perjalananan yang akan distudi meliputi: Jumlah perjalanan(Y), Jumlah anggota keluarga (X1), Jumlah pendapatan keluarga per bulan (X2), Jumlah pekerja, mahasiswa dan pelajar (X3), Jumlah sepeda motor yang dimiliki (X4), Jumlah mobil yang di miliki (X5), Jumlah Biaya transportasi (X6), Biaya rekening listrik per bulan (X7), Biaya rekening air per bulan (X8), Luas bangunan (X9).

Lokasi atau daerah yang dipilih untuk studi adalah perumahan Bukit Bambe Driyorejo Gresik, yang terletak di Desa Bambe, Kecamatan Driyorejo Kabupaten Gresik. Perumahan Bukit Bambe terletak di perbatasan antara Kota Surabaya dan Gresik.

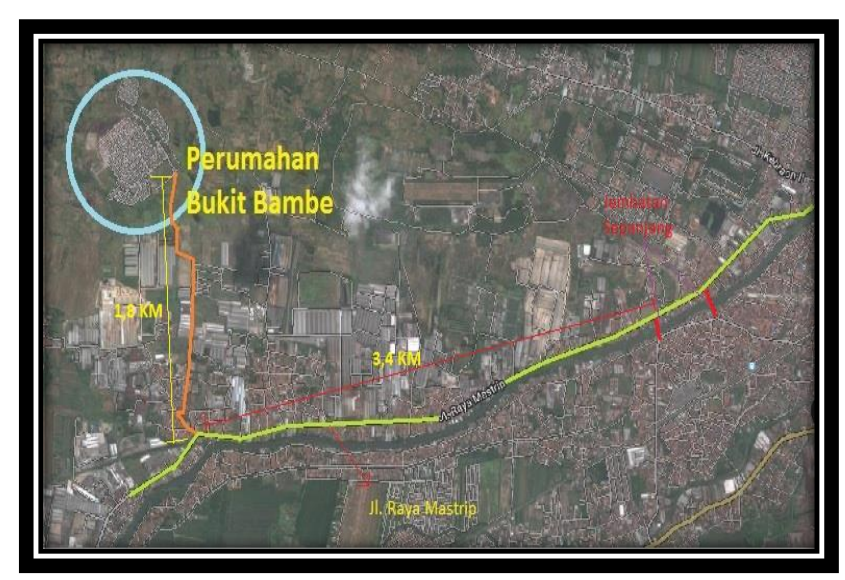

Gambar 1. Foto Udara Lokasi Perumahan Bukit Bambe

Sumber : Google Maps, 2015

\section{METODE PENELITIAN}

Data Primer diperoleh dengan melakukan survei lapangan langsung (Home Interview Survey) secara acak kepada beberapa keluarga dengan jumlah yang sesuai dengan kebutuhan data. Penyusunan kuesioner berdasarkan variabel yang akan digunakan dalam analisa. Adapun variabel variabel yang disurvey yang akan ditabulasikan, adalah Jumlah perjalanan (Y), Jumlah anggota keluarga (X1), Jumlah pendapatan keluarga per bulan (X2), Jumlah anggota keluarga yang bekerja (X3), Jumlah anggota keluarga yang bersekolah/ kuliah (X4), Jumlah sepeda motor yang dimiliki (X5), Jumlah mobil yang di miliki (X6), Jumlah Biaya transportasi (X7), Biaya rekening listrik per bulan (X8), Biaya rekening air per bulan (X9), Luas tanah (X10), Luas Bangunan (X11), Jumlah waktu perjalanan per rumah tangga (X12), Jumlah jarak perjalanan per rumah tangga (X13). 
Data sekunder dalam studi ini di peroleh dari : PT. Bambe Sinar Surya Timur berupa jumlah unit rumah yang sudah terbangan dan yang akan di bangun, dan tipe - tipe rumah di perumahan Bukit Bambe Driyorejo Gresik. RW (Rukun Warga) 06 perumahan Bukit Bambe Gresik yang berupa data jumlah kepala kelarga. Studi pustaka yang berhubungan dengan studi ini, yang bisa diperoleh dari buku refrensi, tugas akhir, skripsi, tesis, dll.

Jumlah sampel ditentukan berdasarkan jumlah populasi dalam artian semakin besar jumlah sampel atau semakin mendekati populasi, maka peluang kesalahan generalisasi semakin kecil, dan sebaliknya makin kecil jumlah sampel atau semakin menjauhi jumlah populasi, maka semakin besar kesalahan generalisasi. Salah satu cara jumlah penentuan jumlah sampel yang digunakan unutuk penelitian ini yaitu dengan menggunakan cara penentuan jumlah sampel dari populasi yang di kembangkan oleh Issac dan Michael, untuk tingkat kesalahan, $1 \%, 5 \%$ dan $10 \%$. Cara yang dikembangkan oleh Issac dan Michael terbilang cukup mudah.

Jumlah sampel kepala keluarga di perumahan Bukit Bambe Driyorejo Gresik sebagai berikut: Populasi (N) kepala keluarga di Bukit Bambe adalah 1278 dan taraf kesalahan $(\alpha) 5 \%$, maka jumlah sampel (S) $=278$.

Tabel 2. Jumlah Kepala Keluarga Per Tipe Rumah

\begin{tabular}{|c|c|c|c|c|c|}
\hline $\begin{array}{c}\text { Ls } \\
\text { Bangunan } \\
\text { / Ls Tanah }\end{array}$ & $\begin{array}{c}\text { Jumlah } \\
\text { unit }\end{array}$ & $\begin{array}{l}\text { Jum } \\
\text { lah } \\
\text { KK }\end{array}$ & $\begin{array}{l}\text { Perhitu } \\
\text { ngan } \\
\text { Strata }\end{array}$ & $\begin{array}{c}\text { Sam } \\
\text { pel }\end{array}$ & $\approx$ \\
\hline \multirow{3}{*}{$21 / 60$} & & & $11 / 1278$ & 2.39 & \\
\hline & 17 & 11 & X 278 & 28 & 11 \\
\hline & \multicolumn{5}{|c|}{$394 / 127$} \\
\hline \multirow{4}{*}{$27 / 72$} & & & $8 X$ & 85.7 & \\
\hline & 498 & 394 & 278 & 058 & 86 \\
\hline & \multicolumn{5}{|c|}{$118 / 127$} \\
\hline & & & $8 X$ & 25.6 & \\
\hline \multirow[t]{3}{*}{$29 / 72$} & 132 & 118 & 278 & 682 & 59 \\
\hline & & & $631 / 127$ & 137. & \\
\hline & & & $8 X$ & 259 & 13 \\
\hline \multirow[t]{2}{*}{$36 / 84$} & 771 & 631 & 278 & 8 & 8 \\
\hline & & & $68 / 1278$ & 14.7 & \\
\hline \multirow[t]{2}{*}{$45 / 105$} & 81 & 68 & X 278 & 919 & 34 \\
\hline & & & $\begin{array}{l}56 / 1278 \\
\end{array}$ & 12.1 & \\
\hline $54 / 120$ & 73 & 56 & X 278 & 815 & 30 \\
\hline Jumlah & 1572 & 1278 & 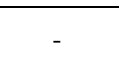 & 278 & $\begin{array}{r}35 \\
8\end{array}$ \\
\hline
\end{tabular}

Sumber : RW 06 Bukit Bambe dan Perhitungan Sampel Strata

1. Perencanaan kuesioner

Dalam merencanakan dan mendesain formulir kuesioner, ada beberapa hal yang harus di perhatikan, antara lain : a. Format dan isi formulir harus mudah di mengerti oleh responden.

b. Isi formulir harus bisa mewakili / menggambarkan kondisi populasi atau sampel yang di studi secara akurat.

c. Isi data kuesioner harus sesuai dengan tujuan studi.

2. Penyebaran kuesioner

Kuesioner di sebar / di bagikan kepada setiap kepala keluarga di perumahan Bukit Bambe Driyorejo Gresik sesuai dengan jumlah sampel yang sudah dihitung / ditentukan sebelumnya

Pengujian model dilakukan untuk mengetahui tingkat keandalan model. Untuk analisis regresi pengujian model yang dilakukan adalah :

\section{Uji korelasi ( $\mathrm{r}$ )}

Keefisien korelasi digunakan untuk mengetahui hubungan antara variabel tidak bebas yaitu jumlah perjalanan perhari dengan variabel bebasnya apakah hubungan kuat atau tidak. Hubungan dinyatakan kuat apabila nilai (r) mendekati 1 atau -1 sedangkan hubungan dinyatakan lemah apabila nilai (r) mendekati 0 (nol)

\section{Koefisien Determinasi ( R2 )}

Koefisien determinasi digunakan untuk mengetahui kontribusi variabel bebas terhadap variabel terikat.

$\mathrm{Uji}$ - t dilakukan untuk melihat apakah parameter yang melekat pada variabel bebas cukup berarti (signifikan) terhadap suatu konstanta (a) nol dan sebaliknya. Kalau signifikan, maka variabel bebas yang terkait dengan parameter harus ada dalam model. Uji - t dapat di terima, apabila nilai thitung. Uji - F digunakan untuk menguji keberartian / signifikasi dari parameter regresi secara keseluruhan atau dengan kata lain untuk menguji kecocokan model. Sama halnya dengan uji - t, uji $\mathrm{F}$ dinyatakan di terima, apabila nilai thitung $>\mathrm{t}$ tabel.

Pengujian normalitas data dengan (X2) dilakukan untuk mengetahui apakah variabel terdistribusi normal atau tidak. Kriteria chi kuadran yaitu apabila $\mathrm{X} 2$ hitung > X2 tabel maka variabel tidak terdistribusi normal, dan jika X2 hitung $<$ X2 tabel, maka variabel terdistribusi normal. Uji kesamaan dua variabel (homogenitas) digunakan untuk menguji apakah kedua data tersebut homogen yaitu dengan membandingkan kedua variabelnya. Jika kedua variabel sama besarnya, maka uji homogenitas tidak perlu dilakukan lagi karena datanya sudah dianggap homogen (sama). Analisa kinerja jaringan jalan di gunakan untuk mengetahui bagaimana tingkat pelayanan (LOS) dari jalan raya 
Mastrip yang dilalui oleh penduduk perumahan. Untuk menghitung kinerja jaringan jalan menggunakan acuan dari Manual Kapasitas Jalan Indonesia (MKJI). Dalam analisa kinerja jaringan jalan ada beberapa tahapan yaitu Menghitung kapasitas jalan yang diperoleh dari survei inventori pengukuran geometrik jalan Raya Mastrip. Menghitung volume lalu lintas yang di peroleh dari hasil survei lalu lintas selama 15 jam $(06.00-21.00$ WIB) di pintu gerbang Bukit Bambe dan di jalan Raya Mastrip. Menganalisa derajat kejenuhan (DS) jalan Raya Mastrip. Merencanakan rekayasa lalu lintas yang tepat untuk jalan Raya Mastrip.

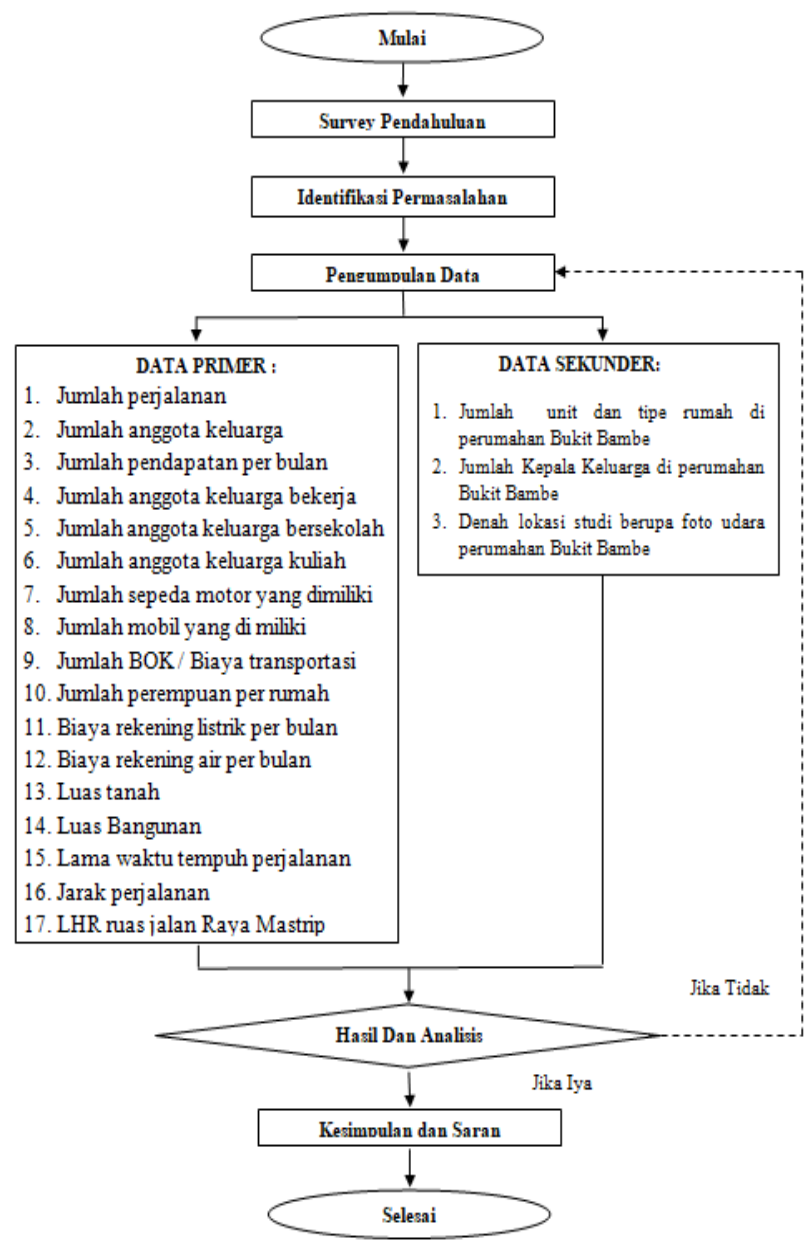

Gambar 2. Diagram Alir Pelaksanaan Studi

\section{HASIL DAN PEMBAHASAN}

Karakteristik Rumah Tangga,Jumlah anggota keluarga berdasarkan tipe rumah. Hasil rekapitulasi data jumlah anggota keluarga penduduk perumahan Bukit Bambe yang di peroleh dari penyebaran kuesioner pada 358 responden adalah sebagai berikut :

Tabel 3. Jumlah Anggota Keluarga

\begin{tabular}{cccccccccc}
\hline $\begin{array}{c}\text { N } \\
\text { o. }\end{array}$ & $\begin{array}{c}\text { Jumlah } \\
\text { Keluarga }\end{array}$ & 21 & 27 & 29 & 36 & 45 & 54 & $\begin{array}{c}\text { Tot } \\
\text { al }\end{array}$ & $\%$ \\
\hline 1 & 1 & 0 & 1 & 2 & 0 & 1 & 0 & 4 & $\begin{array}{c}1,1 \\
2\end{array}$ \\
\hline 2 & 2 & 0 & 4 & 4 & 4 & 2 & 1 & 15 & $\begin{array}{c}4,1 \\
9\end{array}$ \\
\hline 3 & 3 & 7 & 23 & 12 & 36 & 11 & 7 & 96 & $\begin{array}{c}26 \\
82\end{array}$ \\
\hline 4 & 4 & 4 & 39 & 23 & 81 & 15 & 17 & $\begin{array}{c}17 \\
9\end{array}$ & $\begin{array}{c}50 \\
00\end{array}$ \\
\hline 5 & 5 & 0 & 11 & 14 & 13 & 5 & 4 & 47 & $\begin{array}{c}13, \\
13\end{array}$ \\
\hline 6 & $>5$ & 0 & 8 & 4 & 4 & 0 & 1 & 17 & $\begin{array}{c}4,7 \\
5\end{array}$ \\
\hline
\end{tabular}

Sumber : Hasil Survei Lapangan

Berdasarkan tabel dan grafik di atas diketahui bahwa rata - rata (mayoritas) jumlah anggota keluarga penduduk perumahan Bukit Bambe berjumlah 4 orang dengan total $179 \mathrm{kk}$ dan nilai persentase sebesar $50 \%$. Sedangkan rata - rata (mayoritas) jumlah anggota keluarga untuk masing - masing tipe rumah yaitu pada tipe 21 berjumlah 3 orang dengan jumlah $7 \mathrm{KK}$, pada tipe 27 berjumlah 4 orang sebanyak $39 \mathrm{KK}$, pada tipe 29 berjumlah 4 orang sebanyak $23 \mathrm{KK}$, pada tipe 36 berjumlah 4 orang sebanyak $81 \mathrm{KK}$, pada tipe 45 berjumlah 4 orang sebanyak $15 \mathrm{KK}$ dan pada tipe 54 berjumlah 4 orang sebanyak $17 \mathrm{KK}$. 
Karakteristik Perjalanan,Jumlah Biaya Transportasi Tabel 4. Jumlah Biaya Transportasi

\begin{tabular}{cccccccc}
\hline No. & $\begin{array}{c}\text { Jumlah Biaya } \\
\text { Transportasi } \\
\text { (Rp.) }\end{array}$ & 21 & 27 & 29 & 36 & 45 & 54 \\
\hline 1 & $0-19.999$ & 9 & 43 & 26 & 66 & 19 & 19 \\
\hline 2 & $\begin{array}{c}20.000- \\
39.999\end{array}$ & 2 & 36 & 25 & 63 & 15 & 5 \\
\hline 3 & $\begin{array}{c}40.000- \\
59.999\end{array}$ & 0 & 5 & 6 & 7 & 0 & 2 \\
\hline 4 & $>60.000$ & 0 & 2 & 2 & 2 & 0 & 4 \\
\hline
\end{tabular}

Sumber : Hasil Survei Lapangan.

Berdasarkan tabel dan grafik di atas diketahui bahwa rata - rata (mayoritas) jumlah biaya transportasi penduduk perumahan Bukit Bambe sebesar Rp. 0 - 19.999 dengan jumlah 182 KK dan nilai persentase $50,84 \%$. Sedangkan rata - rata (mayoritas) biaya rekening air untuk masing masing tipe rumah yaitu pada tipe 21 sebesar Rp. 0 - 19.999 sebanyak 9 KK, pada tipe 27 sebesar Rp. 0 - 19.999 sebanyak $43 \mathrm{KK}$, pada tipe 29 sebesar Rp. 0 19.999 sebanyak $26 \mathrm{KK}$, pada tipe 36 sebesar Rp. 0 - 19.999 sebanyak $66 \mathrm{KK}$, pada tipe 45 sebesar Rp. 0 - 19.999 sebanyak $19 \mathrm{KK}$ dan pada tipe 54 sebesar Rp. 0 - 19.999 sebanyak 19 KK.

Jumlah Waktu Perjalanan

Tabel 5. Jumlah Waktu Perjalanan

\begin{tabular}{|c|c|c|c|c|c|c|c|c|c|}
\hline $\begin{array}{c}\text { No } \\
\text {. }\end{array}$ & $\begin{array}{c}\text { Jumlah } \\
\text { Waktu } \\
\text { Perjalana } \\
\mathrm{n} \text { (menit) }\end{array}$ & 21 & 27 & Jum & $\mathrm{h} \mathrm{Kl}$ & 45 & 54 & $\begin{array}{c}\text { Tot } \\
\text { al }\end{array}$ & $\%$ \\
\hline 1 & $0-30$ & 2 & 30 & 11 & 44 & 5 & 10 & 102 & $\begin{array}{l}22, \\
63\end{array}$ \\
\hline 2 & $31-60$ & 7 & 34 & 18 & 58 & 14 & 10 & 141 & $\begin{array}{l}39, \\
39\end{array}$ \\
\hline 3 & $61-90$ & 2 & 10 & 14 & 28 & 7 & 5 & 66 & $\begin{array}{l}25, \\
70\end{array}$ \\
\hline 4 & $91-120$ & 0 & 7 & 9 & 6 & 5 & 2 & 29 & $\begin{array}{c}8,9 \\
4\end{array}$ \\
\hline 5 & $>120$ & 0 & 5 & 7 & 2 & 3 & 3 & 20 & $\begin{array}{c}4,4 \\
7\end{array}$ \\
\hline
\end{tabular}

Sumber : Hasil Survei Lapangan.

Berdasarkan tabel dan grafik di atas diketahui bahwa rata - rata (mayoritas) jumlah waktu perjalanan penduduk perumahan Bukit Bambe selama 31 - 60 menit dengan jumlah $141 \mathrm{KK}$ dan nilai persentase $39,39 \%$. Sedangkan rata - rata (mayoritas) jumlah waktu perjalanan untuk masing masing tipe rumah yaitu pada tipe 21 selama 31 60 menit sebanyak 7 KK, pada tipe 27 selama 31 60 menit sebanyak $34 \mathrm{KK}$, pada tipe 29 selama 31 60 menit sebanyak $18 \mathrm{KK}$, pada tipe 36 selama 31 60 menit sebanyak $58 \mathrm{KK}$, pada tipe 45 yaitu elama 31 - 60 menit sebanyak $11 \mathrm{KK}$ dan pada tipe 54 selama $31-60$ menit sebanyak $10 \mathrm{KK}$.
Jumlah Jarak Perjalanan

Tabel 6. Jumlah Jarak Perjalanan

\begin{tabular}{|c|c|c|c|c|c|c|c|c|c|}
\hline No. & $\begin{array}{c}\text { Jumlah } \\
\text { Jarak } \\
\text { Perjala } \\
\text { nan } \\
(\mathrm{km}) \\
\end{array}$ & 21 & 27 & Jum & KK & 45 & 54 & $\begin{array}{l}\text { To } \\
\text { tal }\end{array}$ & $\%$ \\
\hline 1 & $0-15$ & 0 & 32 & 9 & 31 & 5 & 4 & 81 & $\begin{array}{c}22,6 \\
3\end{array}$ \\
\hline 2 & $16-30$ & 6 & 24 & 13 & 60 & 10 & 10 & $\begin{array}{c}12 \\
3\end{array}$ & $\begin{array}{c}34,3 \\
6\end{array}$ \\
\hline 3 & $31-45$ & 4 & 19 & 13 & 35 & 11 & 10 & 92 & $\begin{array}{c}25,7 \\
0\end{array}$ \\
\hline 4 & $46-60$ & 1 & 8 & 11 & 8 & 4 & 0 & 32 & 8,94 \\
\hline 5 & $61-75$ & 0 & 0 & 8 & 2 & 4 & 2 & 16 & 4,47 \\
\hline 6 & $76-90$ & 0 & 3 & 3 & 1 & 0 & 4 & 11 & 3,07 \\
\hline 7 & $>90$ & 0 & 0 & 2 & 1 & 0 & 0 & 3 & 0,84 \\
\hline
\end{tabular}

Sumber : Hasil Survei Lapangan, 2015

Berdasarkan tabel dan grafik di atas diketahui bahwa rata - rata (mayoritas) jumlah jarak perjalanan penduduk perumahan Bukit Bambe berjarak 16 - $30 \mathrm{~km}$ dengan jumlah $123 \mathrm{KK}$ dan persentase $34,36 \%$. Sedangkan rata - rata (mayoritas) jumlah waktu perjalanan untuk masing masing tipe rumah yaitu pada tipe 21 berjarak 16 $30 \mathrm{~km}$ sebanyak $6 \mathrm{KK}$, pada tipe 27 berjarak $0-15$ $\mathrm{km}$ sebanyak $32 \mathrm{KK}$, pada tipe 29 berjarak $16-30$ $\mathrm{km}$ dan 31 - $45 \mathrm{~km}$ masing - masing sebanyak 13 $\mathrm{KK}$, pada tipe 36 berjarak 16 - $30 \mathrm{~km}$ sebanyak 60 KK, pada tipe 45 berjarak $31-45 \mathrm{~km}$ sebanyak 11 KK dan pada tipe 54 berjarak $16-30 \mathrm{~km}$ dan 31 $45 \mathrm{~km}$ masing - masing sebanyak $10 \mathrm{KK}$.

\section{Analisa Model Bangkitan Tipe 21}

Uji asumsi linieritas bertujuan untuk mengetahui apakah kedua variabel mempunyai hubungan linier secara signifikan atau tidak. kitan Dasar pengambilan keputusan dalam uji linieritas dapat dilakukan dengan dua cara yaitu Dengan melihat nilai signifikansi (sig.). Jika nilai signifikansi (sig.) $>0.05$ maka terdapat hubungan linier secara signifikan antara variabel $\mathrm{X}$ dengan Variabel $\mathrm{Y}$. Dengan melihat nilai Fhitung. Jika nilai Fhitung < Ftabel maka terdapat hubungan linier secara signifikan antara variabel $\mathrm{X}$ dan variabel $\mathrm{Y}$. Dalam pengujian ini dibantu oleh aplikasi komputer SPSS 17. Berikut ini tabel hasil uji asumsi linieritas data responden penduduk perumahan Bukit Bambe tipe 21 dengan jumlah responden $11 \mathrm{KK}$. 
Tabel 7. Rekapitulasi Hasil Uji Linieritas Pada Tipe 21

\begin{tabular}{|c|c|c|c|}
\hline Variabel & Nilai F & Sig & Tingkat hubungan \\
\hline $\mathrm{X} 1$ & 2,014 & 0,190 & Signifikan \\
\hline $\mathrm{X} 2$ & 0,168 & 0,969 & Signifikan \\
\hline $\mathrm{X} 3$ & 0,557 & 0,447 & Signifikan \\
\hline $\mathrm{X} 4$ & 1,628 & 0,238 & Signifikan \\
\hline $\mathrm{X} 5$ & 0,238 & 0,638 & Signifikan \\
\hline $\mathrm{X} 6$ & 2,955 & 0,201 & Signifikan \\
\hline $\mathrm{X} 7$ & 2,103 & 0,201 & Signifikan \\
\hline $\mathrm{X} 8$ & 2,014 & 0,190 & Signifikan \\
\hline $\mathrm{X} 9$ & 2,014 & 0,190 & Tidak Signifikan \\
\hline $\mathrm{X} 10$ & 0,168 & 0,969 & Tidak Signifikan \\
\hline $\mathrm{X} 11$ & 0,557 & 0,447 & Signifikan \\
\hline $\mathrm{X} 12$ & 1,628 & 0,238 & Signifikan \\
\hline
\end{tabular}

Sumber : Output SPSS 17

Dari hasil Output SPSS, diketahui bahwa semua variabel $X$ mempunyai hubungan linier secara signifikan dengan variabel $\mathrm{Y}$ kecuali variabel $\mathrm{X} 9$ dan X10 tidak memiliki hubungan karena nilai sig tidak muncul dalam output SPSS yang disebabkan oleh kedua data variabel tersebut tidak bervariasi.

Uji Normalitasini dilakukan untuk mengetahui data terdistribusi normal atau tidak. Dalam pengujian ini dibantu oleh aplikasi komputer SPSS 17. Data dikatakan terdistribusi normal apabila nilai (Sig. > 0,05). Berikut ini tabel hasil uji normalitas data responden penduduk perumahan Bukit Bambe tipe 21 dengan jumlah responden $11 \mathrm{KK}$.

Tabel 8. Rekapitulasi Hasil Uji Normalitas Pada Tipe 21

\begin{tabular}{|c|c|c|}
\hline Variabel & Nilai Sig. & Kesimpulan \\
\hline $\mathrm{Y}$ & 0,015 & Tidak Normal \\
\hline $\mathrm{X} 1$ & 0,000 & Tidak Normal \\
\hline $\mathrm{X} 2$ & 0,184 & Normal \\
\hline $\mathrm{X} 3$ & 0,007 & Tidak Normal \\
\hline $\mathrm{X} 4$ & 0,000 & Tidak Normal \\
\hline $\mathrm{X} 5$ & 0,000 & Tidak Normal \\
\hline $\mathrm{X} 6$ & 0,038 & Tidak Normal \\
\hline $\mathrm{X} 7$ & 0,200 & Normal \\
\hline $\mathrm{X} 8$ & 0,000 & Tidak Normal \\
\hline X9 & - & Tidak Normal \\
\hline $\mathrm{X} 10$ & - & Tidak Normal \\
\hline $\mathrm{X} 11$ & 0,080 & Normal \\
\hline $\mathrm{X} 12$ & 0,002 & Tidak Normal \\
\hline
\end{tabular}

Sumber : Output SPSS 17.

Dari hasil Output SPSS, diketahui bahwa ada tiga variabel yang terdistriusi normal yaitu Jumlah Pendapatan, Jumlah Rekening Listrik, dan Jumlah Waktu Perjalanan. Dikarenakan tidak semua variabel terdistribusi normal maka pengujian data beralih ke pengujian non parametrik karena pengujian non parametrik tidak mengharuskan data terdistribusi normal. Uji normalitas non parametrik data responden penduduk perumahan Bukit Bambe tipe 21 dengan jumlah responden $11 \mathrm{KK}$ sebagai berikut :

Tabel 9. Rekapitulasi Hasil Uji Normalitas Non Parametrik Pada Tipe 21

\begin{tabular}{ccc}
\hline Variabel & $\begin{array}{c}\text { Nilai Asymp. } \\
\text { Sig. }\end{array}$ & Kesimpulan \\
\hline Y & 0,346 & Normal \\
\hline X1 & 0,058 & Normal \\
\hline X2 & 0,710 & Normal \\
\hline X3 & 0,276 & Normal \\
\hline X4 & 0,081 & Normal \\
\hline X6 & 0,058 & Normal \\
\hline X7 & 0,454 & Normal \\
\hline X8 & 0,955 & Normal \\
\hline X9 & 0,058 & Normal \\
\hline X10 & - & Tidak Normal \\
\hline X11 & - & Tidak Normal \\
\hline X12 & 0,557 & Normal \\
\hline Sumber : & 0,200 & Normal
\end{tabular}

Sumber : Output SPSS 17.

Dari hasil Output SPSS, diketahui bahwa ada dua variabel yang terdistriusi normal yaitu luas bangunan dan luas tanah yang disebabkan data kedua variabel itu tidak variatif.

Uji Chi Square (homogenitas) ini dilakukan untuk memeriksa kebergantungan dan homogenitas dari suatu data. Dalam pengujian ini dibantu oleh aplikasi komputer SPSS 17. Data dikatakan homogen (sama) apabila nilai (Asymp. Sig. > 0,05). Berikut ini tabel hasil uji homogenitas data responden penduduk perumahan Bukit Bambe tipe 21 dengan jumlah responden $11 \mathrm{KK}$.

Tabel 10. Rekapitulasi Hasil Chi Square Pada Tipe

\begin{tabular}{ccc}
\multicolumn{2}{c}{21} & \\
\hline Variabel & Nilai Asymp. Sig. & Kesimpulan \\
\hline X1 & 0,366 & Homogen \\
\hline X2 & 0,901 & Homogen \\
\hline X3 & 0,178 & Homogen \\
\hline X4 & 0,078 & Homogen \\
\hline X5 & 0,366 & Homogen \\
\hline X6 & 0,987 & Homogen \\
\hline X7 & 0,866 & Homogen \\
\hline X8 & 0,366 & Homogen \\
\hline X9 & - & Tidak Homogen \\
\hline X10 & - & Tidak Homogen \\
\hline X11 & 0,996 & Homogen \\
\hline X12 & 0,901 & Homogen \\
\hline Y & 0,234 & Homogen
\end{tabular}

Sumber : Output SPSS 17.

Dari hasil Output SPSS, diketahui bahwa ada dua variabel yang tidak homogen (heterogen) yaitu luas bangunan dan luas tanah yang disebabkan data kedua variabel itu tidak bervariasi. 
Analisis Korelasi Antara Variabel Terikat dengan Variabel Bebas Analisis korelasi digunakan untuk mengetahui hubungan dan arah hubungan antar variabel Dependen (Y) dan Independen (X). Dua variabel atau lebih dikatakan mempunyai hubungan (correlated) apabila memliki nilai korelasi $(\mathrm{r}>0,5)$ dan tingkat signifikasi (sig. $<0,05$ ). Semakin tinggi nilai korelasi maka semakin tinggi juga keeratan hubungan antar variabel. Berikut ini tabel hasil analisis korelasi antar variabel bangkitan perjalanan penduduk Bukit Bambe tipe 21 Gresik yang diperoleh dari survei di lapangan dengan jumlah 11 responden.

Tabel 11. Rekapitulasi Hasil Korelasi antara Variabel Y dan X Pada Tipe 21

\begin{tabular}{ccccc}
\hline $\begin{array}{c}\text { Variabe } \\
1\end{array}$ & $\begin{array}{c}\text { Variabe } \\
1\end{array}$ & $\mathrm{R}$ & Sig. & Kesimpulan \\
\hline & $\mathrm{X} 1$ & 0,396 & 0,114 & Tidak ada hubungan \\
\cline { 2 - 5 } & $\mathrm{X} 2$ & 0,168 & 0,311 & Tidak ada hubungan \\
\cline { 2 - 5 } $\mathrm{Y}$ & $\mathrm{X} 3$ & 0,873 & 0,000 & $\begin{array}{c}\text { Signifikan (ada } \\
\text { hubungan) }\end{array}$ \\
\cline { 2 - 5 } & $\mathrm{X} 4$ & 0,471 & 0,072 & Tidak ada hubungan \\
\cline { 2 - 5 } & $\mathrm{X} 5$ & $-\overline{132}$ & 0,349 & Tidak ada hubungan \\
\cline { 2 - 5 } & $\mathrm{X} 6$ & 0,228 & 0,250 & Tidak ada hubungan \\
\cline { 2 - 5 } & $\mathrm{X} 7$ & 0,736 & 0,005 & $\begin{array}{c}\text { Signifikan (ada } \\
\text { hubungan) }\end{array}$ \\
\hline Variabe & Variabe & 0,396 & 0,114 & Tidak ada hubungan \\
\hline 1 & 1 & $\mathrm{R}$ & Sig. & Kesimpulan \\
\hline & $\mathrm{X} 9$ & - & - & Tidak ada hubungan \\
\hline Y & $\mathrm{X} 10$ & - & - & Tidak ada hubungan \\
\hline & $\mathrm{X} 11$ & 0,050 & 0,441 & Tidak ada hubungan \\
\hline X12 & 0,127 & 0,355 & Tidak ada hubungan \\
\hline Sumber & Output SPSS & &
\end{tabular}

Sumber : Output SPSS 17.

Berdasarkan hasil dari tabel di atas diketahui bahwa tidak semua variabel Independen (X) memiliki hubungan (korelasi) dengan variabel (Y). Variabel Independen (X) yang memiliki korelasi dengan variabel (Y) yaitu X3 (jumlah pegawai, mahasiswa dan pelajar); dan X7 (biaya rekening listrik) karena memiliki nilai $(r>0,5)$ dan nilai $(\operatorname{sig}<0,05)$.

Analisa regresi linier sederhana dilakukan untuk menguji pengaruh antara variabel terikat $(\mathrm{Y})$ dengan satu variabel (X). Varibel yang di pilih yaitu variabel yang memiliki kriteria signifikasi (R2 > 0,5). Berikut ini adalah hasil rekapitulasi dari analisa regresi linier sederhana dari varibel bangkitan perjalanan penduduk Bukit Bambe tipe 21 yang diperoleh dari survei di lapangan dengan jumlah 11 responden.

Analisa model regresi linier berganda ini dilakukan sebagai tahap lanjutan dari analisa variabel variabel yang mempengaruhi karakteristik perjalanan variabel terikat dengan variabel bebas serta analisa regresi sederhana. Analisa ini untuk membentuk model bangkitan perjalanan yang paling sesuai untuk perumahan Bukit Bambe. Berikut ini adalah hasil rekapitulasi dari analisa regresi linier sederhana dari varibel bangkitan perjalanan penduduk Bukit Bambe tipe 21 yang diperoleh dari survei di lapangan dengan jumlah 11 responden.

Pemilihan model terbaik

Dilakukan untuk memilih model terbaik yang bisa digunakan untuk model bangkitan perjalanan penduduk perumahan Bukit Bambe Gresik. Berikut ini adalah hasil rekapitulasi dari analisa regresi linier sederhana dari varibel bangkitan perjalanan penduduk Bukit Bambe tipe 21 yang diperoleh dari survei di lapangan dengan jumlah 11 responden.

Tabel 12. Pemilihan Model Terbaik Pada Tipe 21

\begin{tabular}{|c|c|c|c|c|c|c|}
\hline $\begin{array}{c}\text { Mode } \\
1\end{array}$ & Var & $\begin{array}{l}\text { Koef. } \\
\text { Reg. }\end{array}$ & $\mathrm{R} 2$ & $\begin{array}{l}\text { Asy } \\
\text { mp. } \\
\text { Sig. }\end{array}$ & $\begin{array}{c}\text { Tolera } \\
\text { nce }\end{array}$ & VIP \\
\hline \multirow{2}{*}{1} & Konst & 0,174 & 0,8 & 0,00 & & \\
\hline & $\mathrm{X} 3$ & 1,870 & 04 & 1 & 1,000 & 1,000 \\
\hline \multirow{3}{*}{2} & Konst & $-3,586$ & \multirow{3}{*}{$\begin{array}{r}0,8 \\
63\end{array}$} & \multirow{3}{*}{$\begin{array}{r}0,00 \\
0\end{array}$} & & \\
\hline & X3 & 1,545 & & & 0,711 & 1,407 \\
\hline & $\mathrm{X} 7$ & $5,241 \mathrm{E}-5$ & & & 0,711 & 1,407 \\
\hline
\end{tabular}

Sumber : Output SPSS 17, 2015

Berdasarkan tabel analisa diatas tersebut maka akan dipilih satu model terbaik yang akan digunakan untuk menentukan model bangkitan perjalanan penduduk perumahan Bukit Bambe Gresik. Model bangkitan terbaik dalam tabel tersebut adalah model 2. Model perjalanan yang terpilih tersebut memiliki variabel - variabel bebas berupa X3 (Jumlah pekerja, mahasiswa dan pelajar) dan X7 (Jumlah Rekening Listrik). Beberapa dasar pertimbangan pemilihan model tersebut adalah sebagai berikut, Nilai koefisien determinasi model 2 paling tinggi yaitu 0,863 yang berarti bahwa variabel - variabel bebas pada model 2 mempengaruhi variabel terikat sebesar $86,3 \%$. Nilai uji non parametrik (friedmen) menghasilkan asymp. Sig. sebesar 0,000. Uji multikolinieritas tahap 2 memiliki nilai Tolerance $0,711(>0,1)$ dan nilai VIF $1,407(<10)$, sehingga layak untuk dijadikan model.

Berdasarkan proses regresi linier diatas terpilih model 2, maka persamaan tersebut dapat dirumuskan sebagai berikut : $Y=\mathbf{- 3 , 5 9 6}+\mathbf{1 , 5 4 5 ~ X 3}$ + 5,241E-5 X7

Keterangan : $\mathrm{Y}=$ Jumlah Perjalanan, $\mathrm{X} 3=$ Jumlah pekerja, mahasiswa dan pelajar, $\mathrm{X} 7=$ Biaya rekening listrik

Proteksi/Desember 2020 Volume 2 No. 2 
Persamaan tersebut dapat ditafsirkan bahwa setiap tambahan jumlah pegawai, mahasiswa dan pelajar per rumah tangga akan meningkatkan bangkitan perjalanan sebesar 1,545 perjalanan per hari dan setiap tambahan biaya rekening listrik per rumah tangga akan meningkatkan bangkitan perjalanan sebesar 5,241E-5 perjalanan perhari.

\section{Volume Bangkitan Pergerakan Berdasarkan Model Yang Dihasilkan}

Untuk mengetahui volume bangkitan diperlukan volume lalu lintas eksisting yang terjadi pada pintu gerbang perumahan Bukit Bambe. Valume lalu lintas di pintu gerbang perumahan Bukit Bambe adalah sebagai berikut :

Tabel 13. Volume Lalu Lintas Di Pintu Gerbang Perumahan Bukit Bambe

\begin{tabular}{|c|c|c|c|c|c|c|}
\hline \multirow{2}{*}{ No. } & \multirow{2}{*}{ Jam } & \multicolumn{3}{|c|}{ Total 2 arah } & \multirow{2}{*}{$\begin{array}{c}\mathrm{V} \\
\text { kend/jam }\end{array}$} & \multirow{2}{*}{$\begin{array}{c}\mathrm{V} / \mathrm{V} \\
\text { total } \\
(\%)\end{array}$} \\
\hline & & MC & LV & UM & & \\
\hline 1 & $06.00-07.00$ & 495 & 28 & 8 & 531 & 10 \\
\hline 2 & $07.00-08.00$ & 649 & 54 & 6 & 709 & 13 \\
\hline 3 & $08.00-09.00$ & 256 & 35 & 3 & 294 & 5 \\
\hline 4 & $09.00-10.00$ & 251 & 42 & 2 & 295 & 5 \\
\hline 5 & $10.00-11.00$ & 243 & 36 & 6 & 285 & 5 \\
\hline 6 & $11.00-12.00$ & 293 & 26 & 6 & 325 & 6 \\
\hline 7 & $12.00-13.00$ & 322 & 27 & 9 & 358 & 6 \\
\hline 8 & $13.00-14.00$ & 310 & 28 & 3 & 341 & 6 \\
\hline 9 & $14.00-15.00$ & 327 & 24 & 5 & 356 & 6 \\
\hline 10 & $15.00-16.00$ & 319 & 29 & 6 & 354 & 6 \\
\hline 11 & $16.00-17.00$ & 378 & 49 & 6 & 433 & 8 \\
\hline 12 & $17.00-18.00$ & 514 & 62 & 3 & 579 & 10 \\
\hline 13 & $18.00-19.00$ & 299 & 36 & 2 & 337 & 6 \\
\hline 14 & $19.00-20.00$ & 188 & 19 & 3 & 210 & 4 \\
\hline 15 & $20.00-21.00$ & 167 & 12 & 1 & 180 & 3 \\
\hline & Jumlah & 5011 & 507 & 69 & 5587 & 100 \\
\hline
\end{tabular}

Sumber : Hasil Survei Lapangan.

Berdasarkan dari tabel di atas dapat diketahui bahwa volume lalu lintas tertinggi terjadi pada pukul 07.00 - 08.00 WIB yaitu sebesar 709 $\mathrm{kend} / \mathrm{jam}$ atau sebesar $13 \%$. Selanjutnya dari tabel di atas persentase V/Vtotal akan diaplikasikan ke volume bangkitan perjalanan berdasarkan model yang dihasilkan. V/Vtot didapat dari persentase volume kendaraan dalam satu jam per jumlah volume kendaraan satu hari $(06.00-21.00 \mathrm{WIB})$. V/Vtot digunakan sebagai acuan kontribusi volume kendaraan/hari ke volume kendaraan/jam.
Berdasarkan tabel perhitungan diatas dapat diketahui bahwa volume paling tinggi terjadi pada jam 07.00 - 08.00 WIB yaitu sebesar 187,89 smp/jam. Volume kendaraan pada waktu yang sama di jalan raya Mastrip sebesar 1.608,65 smp/jam (tabel 4.89). Dengan demikian bangkitan perjalanan perumahan Bukit Bambe berkontribusi sebesar $12 \%$. Sedangkan volume lalu lintas jalan raya Mastrip dengan asumsi tanpa ada kontribusi dari perumahan Bukit Bambe yaitu 1.608,65 - 187,89= $1.420,76 \mathrm{smp} / \mathrm{jam}$.

Simulasi Jumlah Bangkitan Setelah Kavling dan Unit Rumah Terisi Penuh Saat ini unit rumah yang sudah terbangun di perumahan Bukit Bambe yaitu 1.572 unit dan sudah terisi 1.278 unit. Menurut rencana perumahan Bukit Bambe masih akan terus berkembang hingga 2.000 unit rumah yang terbangun. Apabila 2.000 unit sudah terbangun dan sudah terisi penuh, tentunya jumlah bangkitan yang ditimbulkan akan berbeda dengan kondisi saat ini. Maka dari itu perlu adanya simulasi bangkitan perjalanan pada saat kondisi tersebut seperti ini :

$\mathrm{Y}=0,088+1,847 \mathrm{X} 3+2,560 \mathrm{E}-6 \mathrm{X} 6+0,004 \mathrm{X} 11$ $=0,088+(1,847 \times 3,1 \times 2.000)+(2,560 \mathrm{E}-6 \times 21,5$ x 2.000) $+(0,004 \times 53,7 \times 2.000)=0,088+11.451,4$ $+0,11008+429,6=11.881$ perjalanan/hari.

Dari perhitungan diatas diketahui bahwa volume lalu lintas pada 10 tahun mendatang sebesar $1.648,85 \mathrm{smp} / \mathrm{jam}$. Setalah volume lalu lintas pada 10 tahun mendatang diketahui, maka besarnya bangkitan dengan asumsi kapasitas jalan Raya Mastrip tetap adalah sebagai berikut :

Tabel 14. Perhitungan Bangkitan Perjalanan Dimasa yang Akan Datang

\begin{tabular}{cccccccc}
\hline V' & C & DS & LOS & $\begin{array}{c}\mathrm{V}^{\prime} \\
\text { Bang } \\
\text { kitan }\end{array}$ & $\begin{array}{c}\text { V' } \\
\text { Total }\end{array}$ & DS & LOS \\
\hline $1.648,85$ & $2.472,54$ & 0,667 & C & 303,54 & $1.952,39$ & 0,790 & D \\
\hline
\end{tabular}

Sumber : Hasil Analisa.

Keterangan :

V': Volume lalu lintas pada 10 tahun mendatang

(smp/jam)

C: Kaspasitas jeksisiting (smp/jam)

DS: Degree of Saturation (Derajat kejenuhan)

LOS: Level of Service (tingkat pelayanan)

V' Bangk: Volume bangkitan baru

V'Total: V' + V' bangkitan 
Berdasarkan tabel perhitungan diatas diketahui bahwa besarnya volume bangkitan baru di jalan Raya Mastrip pada saat unit rumah terisi penuh yaitu sebesar 1.952,39 smp/jam. Dengan kapasitas 2472,54 smp/jam mengahasilkan nilai DS $=0,790$. Kondisi ini membuat tingkat pelayanan jalan Raya Mastrip menurun menjadi LOS D (sebelumnya C).

Simulasi Peningkatan Kinerja Ruas Jalan Raya Mastrip dari hasil analisa simulasi besar bangkitan setelah kavling dan unit rumah terisi penuh yang telah dilakukan sebelumnya, diketahui bahwa kinerja ruas jalan Raya Mastrip berada di LOS E. Hal ini berarti tingkat pelayanan ini memberikan suatu gambaran arus tidak stabil, kecepatan kadang terhenti. Maka dari itu perlu dilakukan beberapa simulasi untuk meningkatkan kinerja ruas jalan raya Mastrip yaitu dengan kapasitas tetap dilakukan manajemen lalin yaitu larangan kendaraan berat (HV) untuk tidak melintas pada jam sibuk

Tabel 4.15 Perhitungan Simulasi Kinerja Jalan Raya Mastrip Tanpa Kendaraan Berat pada Jam Sibuk

\begin{tabular}{ccccccccc}
\hline $\mathrm{V}^{*}$ & $\mathrm{C}$ & $\begin{array}{c}\mathrm{D} \\
\mathrm{S}\end{array}$ & LOS & $\begin{array}{r}\text { V' } \\
\text { Bang } \\
\text { kitan }\end{array}$ & $\begin{array}{c}\text { V' } \\
\text { Total }\end{array}$ & DS & $\begin{array}{c}\text { LO } \\
\text { S }\end{array}$ \\
\hline $1.236,6$ & $2.472,5$ & 0.50 & C & 303,54 & $1.540,1$ & 0,62 & C \\
\hline
\end{tabular}

Sumber : Hasil Analisa

Pelebaran badan jalan total 2 arah menjadi 9 meter dan tidak ada larangan bagi kendaraan berat (HV) untuk melintas pada jam sibuk.

Tabel 15. Perhitungan Simulasi Kapasitas Jalan Raya Mastrip Dengan Perubahan Lebar Badan Jalan Total 2 Arah $9 \mathrm{~m}$

\begin{tabular}{cccccc}
\hline C0 & FCw & FCsp & FCsf & FCcs & C \\
\hline 2900 & 1,25 & 1 & 0.95 & 1 & $3.443,75$ \\
\hline
\end{tabular}

Sumber : Hasil Analisa, 2015

Tabel 16. Perhitungan Simulasi Kinerja Jalan Raya Mastrip Dengan Perubahan Lebar Badan Jalan Total 2 Arah $9 \mathrm{~m}$

\begin{tabular}{ccccccc}
\hline V' & C & DS & LOS & $\begin{array}{c}\text { V' } \\
\text { Bang } \\
\text { kitan }\end{array}$ & $\begin{array}{c}\text { V' } \\
\text { Total }\end{array}$ & DS \\
\hline $1.648,85$ & $3.443,75$ & 0,479 & C & 303,54 & $\begin{array}{c}1.952, \\
39\end{array}$ & 0,567
\end{tabular}

Sumber : Hasil Analisa, 2015

Pelebaran badan jalan total 2 arah menjadi 9 meter dan larangan bagi kendaraan berat (HV) untuk melintas pada jam sibuk.
Tabel 17. Perhitungan Simulasi Kapasitas Jalan Raya Mastrip Dengan Perubahan Lebar Badan Jalan Total 2 Arah $9 \mathrm{~m}$

\begin{tabular}{cccccc}
\hline C0 & FCw & FCsp & FCsf & FCcs & C \\
\hline 2900 & 1,25 & 1 & 0.95 & 1 & 3443.75 \\
\hline
\end{tabular}

Sumber : Hasil Analisa

Tabel 18. Perhitungan Simulasi Kapasitas Jalan Raya Mastrip Dengan Perubahan Lebar Badan Jalan Total 2 Arah 9 m dan Tanpa Kendaraan Berat pada Jam Sibuk

\begin{tabular}{ccccccc}
\hline $\mathrm{V}^{*}$ & $\mathrm{C}$ & DS & LOS & $\begin{array}{c}\mathrm{V}^{\prime} \\
\text { Bang } \\
\text { kitan }\end{array}$ & $\begin{array}{c}\text { V' } \\
\text { Total }\end{array}$ & DS \\
\hline $1.236,64$ & $3.443,75$ & 0,359 & B & 303,54 & $1.540,18$ & 0,447 \\
\hline
\end{tabular}

Sumber : Hasil Analisa

Dari ketiga simulasi diatas dapat diambil keputusan bahwa simulasi yang ketiga merupakan yang paling baik dengan nilai DS $=0,447$ dan tingkat pelayanan jalan berada di LOS B. Selain itu, untuk mengurangi angka kecelakaan lalu lintas di jalan Raya Mastrip, maka perlu ada pembagian lajur dengan marka solid yaitu lajur 1 dengan lebar $2 \mathrm{~m}$ digunakan untuk sepeda motor dan lajur yang lain dengan lebar 2,5 $\mathrm{m}$ digunakan untuk jenis kendaraan roda 4 atau lebih

\section{KESIMPULAN}

Berdasarkan hasil studi yang dilakukan terhadap perumahan Bukit Bambe Driyorejo Gresik karakteristik perjalanan penduduk perumahan Bukit Bambe berdasarkan 358 responden sebagai berikut, Jumlah biaya transportasi 50,84 \% sebesar Rp. 0 - Rp. 19.999,00; Jumlah lama waktu perjalanan $39,39 \%$ selama 31 - 60 menit; Jumlah jarak perjalanan 34,36\% sebesar 16 - $30 \mathrm{~km}$; Moda Transportasi yang digunakan sebesar $73,03 \%$ menggunakan sepeda motor; Tujuan Perjalaan 41,64\% menuju ke zona Surabaya Selatan yaitu kecamatan Karang Pilang, Wiyung, Gayungan, Wonokromo, Dukuh Pakis, Jambangan, LQS Socolo dan Sawahan.

Godel bangkitan perjalanan penduduk perumahan Bukit Bambe Driyorejo sebagai berikut $\mathrm{Y}=0,088+1,847 \mathrm{X} 3+2,560 \mathrm{E}-6 \mathrm{X} 6+$ $0,004 \mathrm{X} 11 \mathrm{R} 2=0,930$ 
Keterangan :

$\mathrm{Y}=$ Jumlah Perjalanan

$\mathrm{X} 3$ = Jumlah pekerja, mahasiswa dan pelajar

$\mathrm{X} 6$ = Jumlah biaya transportasi

X11 = Jumlah waktu perjalanan

Dapat ditafsirkan bahwa setiap tambahan jumlah pegawai, mahasiswa dan pelajar per rumah tangga akan meningkatkan bangkitan perjalanan sebesar 1,847 perjalanan perhari, setiap tambahan jumlah biaya transportasi per rumah tangga akan meningkatkan bangkitan perjalanan sebesar 2,560E-6 perjalanan per hari dan setiap tambahan jumlah waktu perjalanan per rumah tangga akan meningkatkan bangkitan perjalanan sebesar 0,004 perjalanan per hari.

Dari model bangkitan dan kondisi eksisting jalan Raya Mastrip mengahasilkan DS 0,895 dengan LOS E. Untuk meningkatkan kinerja ruas jalan Raya Mastrip dimasa 10 tahun yang akan datang maka perlu dilakukan pelebaran jalan badan jalan total 2 arah 9 meter dan larangan kendaraan berat $(H V)$ melintas di $\mathrm{jl}$. Raya Mastrip pada jam sibuk (06.00 - 09.00 WIB). Setelah dilakukan hal tersebut kinerja jalan Raya Mastrip berada di LOS B dengan $\mathrm{DS}=0,447$.

\section{REFERENSI}

Alvinsyah \& Soehodho, S. 1997. Dasar - Dasar Sistem Transportasi, Laboratorium Transportasi Jurusan Sipil Fakultas Teknik Universitas Indonesia, Jakarta.

Arifin, J. \& Fauzi, A.. 1999. Mengupas Tuntas Microsoft Excel. 2000. Penerbit PT. Elex Media Komputindo, Jakarta.

Badudu \& Zain. 1994, Kamus Umum Bahasa Indonesiaa Penerbit Pustaka Sinar Hampan, Jakarta.

Blaang, C.D. 1986. Perumahan dan Permukiman sebagai Kebutuhan Pokok, Penerbit Yayasan Obor Indonesia, Jakarta.

Brotowidjoyo, M.D. 1991. Metodologi Penelitian dan Penulisan Karangan ilmiah, Penerbit Liberty, Yogyakarta.

Catanese, Anthony J. 1992. Perencanaan Kota, Edişi II, Penerbit Erlangga.

Darmosudiharjo. M.S. 1993. Bangkitan Lalü Lintas dari Perumahan, Studi Kasus Perumnas Antapani Kotamadya Bandung Jawa Barat, Tesis Bidang Studi Rekayasa Transportasi
Jurusan Teknik Sipil Program Pasca Sağana Institut Teknologi Bandung. i

Departemen Pendidikan dan Kebudayaan. 1988. Kamus Beşar Bahasa Indonesia, Penerbit Balai Pustaka, Jakarta.

Departemen Perhubungan, Pusat Pendidikan dan Latihan Perhubungan Darat Balai Diklat DLLAJR. 1993. Data Publikasi SQT 6, Bekasi.

Departemen Pekerjaan Umum, Direktorat Jenderal Bina Marga. 1997. Manual Kapasitas Jalan Indonesia (MMI), Jakarta

Departemen Pekerjaan Umum dan Tenaga Lisfrik, Direktorat Jenderal Bina Marga, 1976, Peraturan Perencanaan Geometrik Jalan Raya (PPGJR), Badan Penerbit Pekerjaan Umum, Jakarta.

Direktorat Jenderal Perhubungan Darat, Pedoman Teknis Penyusunan Analisis Dampak Lalulintas (Andalin).

Dinas Pekerjaan Umum. 1979. Pedoman Perencanaan Lingkungan Pemukiman Kota.

Hadi, S., 1995, Metodologi Research Jilid 3, Penerbit Andi Offset, Yogyakarta.

Indrajaya, U.W. 2004. Karateristik dan Model Estimasi Bangkitan Perjalanan (Studi Kasus Perumahan Tlogosari Semarang), Tesis Program Pasca Sağana -Universitas Diponegoro, Semarang.

Kamarwan, S.S. 1997. Sistem Transportasi, Penerbit Gunadarma, Jakarta

Kustituanto, B. 1984. Statistik Analisa Runtut Maktu dan Reyesi Korelasi, BPPE, Yogyakarta.

Kelurahan Batursari. 2003. Laporan Monografi Kelurahan Batursari Kecamatan Mranggen Kabupaten Demak Keadaan Bulan November 2003.

Kodoatie, R.J. 2003. Manajemen dan Rekayasa Infrastruktur, Penerbit Pustaka Pelajar.

Yogyakarta

Marzuki. 1997. Metodologi Riset, Penerbit Fakultas Ekonomi Ull, Yogyakarta.

Morlok, E.K. 1988. Pengantar Teknik dan Perencanaan Transportasi, Penerbit Erlangga, Jakarta Pusat.

Nazir, M. 1983. Metodologi Penelitian, Penerbit Ghalia Indonesia, Jakarta.

Ortuzar, Juan de Dios. 1994. Modelling Transport, John Wiley \& Sons, Chichester.

Papacostas, C.S. 1987. Fundamentals offransportation, Prentice - Hall of India, New Delhi

Perencanaan Geometrik Jalan, Diktat Rekayasa Transportasi, Jurusan Teknik Sipil Fakultas Teknik, Institut Bandung.

Proteksi/Desember 2020 Volume 2 No. 2 
Program Pasca Sarjana Universitas Diponegoro. 2003. Pedoman Penulisan Tesis Magister Teknik Sipil, Semarang.

Program Pasca Sarjana Universitas Diponegoro. 2002. Pelatihan Statistik dan Penggunaan spss, Semarang.

Richardson, A.J., 1982, Transport Survey Methods, Departmen of Civil Engineering Monash University

Salter, R. J. 1974. Highway frafiîc Analysis and Design, The Macmillan Press LTD, London and Basing Stoke.

Siswanto, J. 2003. Perumahan dan Pemukiman, Diktat Kuliah Program Magister Teknik Sipil Unversitas Diponegoro, Semarang.

Sugiarti. 2001. Teknik Sampling, Penerbit PT. Gramedia Pustaka Utama, Jakarta.

Swastono, S. 2000. Tarikan Perjalanan Ke Kampus Perguruan Tinggi (Studi Kasus: Kampus UGM), dalam Forum Studi Transportasi Antar Perguruan Tinggi, Prosiding Simposium III, Yogyakarta : Universitas Gadjah Mada.

Tamin, O.Z. 1997. Perencanaan dan Permodelan Transportasi, Institut Teknologi Bandung.
Uli, H.D. 1999. Analisis Ability to Pay dan Willingnes to Pay TarifAngkutan Kota (Tesis . Magister Studi kasus : kotamadya Medan),.

Usman, H. \& Akbar, R.P.S. 1995. Pengantar Statistika, Penerbit PT. Burni Aksara, Jakarta.

Wahyono, H. \& Buchori, 1. 1988. Pola Produksi Perjalanan di Kawasan Permukiman Pinggiran Kotamadya Semarang, dalam Forum Studi Transportasi Antar Perguruan Tinggi, Prosiding Simposium I, Institut Teknologi Bandung.

Walpole, R.E. dan Myers, R.H. 1995. 11mu Peluang dan Statistika untuk Insinyur dan Ilmuwan (terjemahan), Penerbit ITB, Bandung.

Warpani, S. 1981. Perencanaan Transport, Institut Teknologi Bandung.

Warpani, S. 1988. Rekayasa Lalu Lintas, Penerbit Bhratara, Jakarta.

Warpani, S. 1990. Merencanakan Sistem Perangkutan, Institut Teknologi Bandung.

Wells, GR. 1985. Traffic Engineering, Penerbit Bhratara Karya, Jakarta 